\title{
Control of Invasive Plants: Ecological and Socioeconomic Criteria for the Decision Making Process
}

\author{
Giselda Durigan $^{1 *}$, Natalia M. Ivanauskas², Maria J. B. Zakia ${ }^{3} \&$ Rodolfo C. R. de Abreu
}

\author{
${ }^{1}$ Floresta Estadual de Assis, Instituto Florestal - IF, Assis, SP, Brasil \\ ${ }^{2}$ Seção de Ecologia Florestal, Instituto Florestal - IF, São Paulo, SP, Brasil \\ ${ }^{3}$ Práxis Socioambiental, Guararema, SP, Brasil \\ ${ }^{4}$ Centro de Recursos Hídricos e Ecologia Aplicada, Escola de Engenharia de São Carlos, \\ Universidade de São Paulo - USP, São Carlos, SP, Brasil
}

\begin{abstract}
Biological invasions have contributed to biodiversity loss, ecosystem degradation, and impairment of ecosystem services worldwide, requiring actions towards their prevention and control. Since human and monetary resources are both limited in most countries, priorities must be settled in the real world of biological invasion prevention and control. To support the decision making process regarding plant species already introduced, we propose a classification key, based upon biogeographical and ecological attributes of the target plant population. The key shall be applied to a particular biogeographical region, based on the premise that a species never invades two distinct ecosystems in the same way. The key categorizes the species according to the potential threats offered to the native biodiversity and ecosystem services in that region. Management strategies are recommended on the basis of both the species performance as invader and its economic importance in the region. We highlight the importance of ecological studies to categorize a species by the threats it offers to a specific ecological region, in order to avoid the waste of efforts and resources with non-risky species. Eradication experiments are equally important to find ecologically, technically and economically viable solutions for the problems derived from biological invasions.
\end{abstract}

Key words: Biological Invasions, Species Categorization, Management, Invasion Status, Impact Evaluation.

\section{Introduction}

The phenomenon of biological invasion comprises the human-mediated introduction of an alien species outside its native range, and its fate in the new range, including survival, establishment, reproduction, dispersal, spread, proliferation, interaction with native species, and influences on the invaded ecosystems (Richardson et al. 2011). In some cases, biological invasions can cause severe biodiversity losses and impairment of ecosystem services by modifying the structure of native communities, and often by changing soil properties, hydrological processes, biogeochemical pools, and fluxes of materials and energy (Armstrong 1995; D’Antonio et al. 1999; Ehrenfeld 2010; Le Maitre et al. 1996; McKinney \& Lockwood 1999; Pysek \& Richardson 2010; Rosenzweig 2001; Simberloff \& Rejmánek 2011). The harmful effects of biological invasions have been widely recognized, and multi-scale programs are in place in many parts of the world to reduce current and future impacts (Pysek \& Richardson 2010). Prevention and control actions

\footnotetext{
*Send correspondence to: Giselda Durigan

Floresta Estadual de Assis, Instituto Florestal - IF, CP 104,

CEP 19802-970, Assis, SP, Brasil

E-mail: giselda@femanet.com.br
}

are necessary to avoid or to reverse the negative effects of biological invasions. For the decision making process, that requires, at first, the identification of those species on which the actions shall be focused.

The terms that should be used to accurately express the different aspects and levels of biological invasions are still controversial (Colautti \& MacIsaac 2004; Daehler 2001; Davis \& Thompson 2000, 2001; Pysek et al. 2004; Rejmánek 1995; Rejmánek et al. 2002, 2013; Richardson et al. 2000, 2011). A general concept has been widely accepted: invasive exotic species (IES) are those that colonize and expand into an ecosystem they have not previously naturally inhabited (Richardson et al. 2000; Williamson 1996; Pysek et al. 1995, 2004). However, this concept includes from 'benign invaders' up to 'transformers', a term proposed by Wells et al. (1986) and adopted by Richardson et al. (2000, 2011). The most controversial issue is the impact of the alien species over the new environment. For most ecologists, an invader not necessarily causes impact in the new range (Richardson et al. 2000, 2011; Daehler 2001; Pysek et al. 2004; Rejmánek et al. 2002, 2013). For some other ecologists and, particularly, for those dealing with 
practical issues related to biological invasions (Cronk \& Fuller 1995; IUCN 2000; CBD 2000; Davis \& Thompson 2000), an invader must have an undesirable impact on its new environment, whether economic, health, or ecological. From the point of view of managers and policy makers, the most important issue is: which species deserve attention and which should be controlled first? The answer to this question requires differentiation among alien species causing impact or not, and, preferably, a hierarchical classification on the basis of extension and severity of impact they cause on the invaded ecosystem. In order to differentiate the invasion status of a plant population, some basic features must be considered, such as: whether the invaded ecosystem is natural or seminatural or the invasive plant is found exclusively in disturbed areas (Pysek et al. 2004). The lack of consensus regarding the operational categorization of an 'invasive species' is a constraint for the decision making process (Colautti \& MacIsaac 2004; Simberloff et al. 2005; Khuroo et al. 2008).

In spite of the uncertainties on definition and categorization of invasive species, official lists of invasive species have been elaborated and published to support public policies towards the prevention and control of biological invasions. In Brazil, official lists of invasive species have been discussed at the leading states like São Paulo, Paraná and Rio de Janeiro. Zenni \& Ziller (2011) presented a pioneer long list of 117 plant species reported as invasive in Brazil. Considering the precaution principle, the initiative of creating a dataset with the occurrence of invasive species is positive. However, as this list lacks criteria, it groups together both the invasive species threatening the native biodiversity and ecosystem functioning (the transformers), and non-risky exotic species that occupy only disturbed areas or do not proliferate. In Brazil, the occurrence of transformer species has been registered, such as Pinus elliotti L. (Zanchetta \& Diniz 2006; Almeida et al. 2010; Abreu \& Durigan 2011), Urochloa decumbens (Stapf) R.D.Webster (Pivello et al. 1999) and Melinis minutiflora P.Beauv. (Hoffmann et al. 2004) in the Cerrado; Archontophoenix cunninghamiana H. Wendl. \& Drude (Dislich et al. 2002) and Artocarpus heterophyllus Lam. (Abreu \& Rodrigues 2010) in the Tropical and Subtropical Rain Forest; Prosopis juliflora (Sw.) DC. in the Caatinga (Tropical Drought-Deciduous Forest and Woodland, Pegado et al. (2006)); and Eragrostis plana Nees in Temperate Grasslands (Medeiros \& Focht 2007). High priority should be given in public policies for these species, in the mentioned ecological regions. On the other hand, there are some examples of unlikely invasions, such as C4 African grasses invading the rain forest or the flesh fruit trees Artocarpus heterophyllus and Mangifera indica L. invading the Cerrado. Nevertheless, they were included in the list from Zenni \& Ziller (2011), as well as Cupressus lusitanica Mill., Sterculia foetida L., and Eucalyptus robusta Sm. - which are not really invasive anywhere in Brazil; and Centella asiatica (L.) Urb. - which has a pantropical distribution. For the absence of robust criteria to differentiate the species by their threat, the lists do not help much in the decision making process. Claiming for improvement of information on invasive plants in the botanical lists, Moro et al. (2012) proposed the classification of species as exotic, naturalized, weed, ruderal or invasive, based on their population size and reproductive success. They suggest that exotic species should be easily categorized by botanists in taxonomic, floristic or phytosociological studies. However, based on these criteria, species like Ricinus communis L. or Leucaena leucocephala (Lam.) de Wit, which spread only over roadsides in most regions of Brazil, do not differ from the 'transformers', being all labeled as 'invasives. This hampers the action prioritization. We agree that the omission of exotic species in botanical studies and regional surveys is negative, and they should always be reported, as proposed by Pysek et al. (2004). However, there is a great risk of labeling all non native species occurring outside their native ranges as simply 'invaders', without the differentiation that gives support for management decisions.

In addition to the problem of all species in the lists grouped in a single category - 'invasive', the national lists ignore that political boundaries are not an ideal framework for the categorization of plant invasion (Pysek et al. 2004). Invasiveness of an alien species varies among ecosystems, being correlated to ecological range, and invasibility of an ecosystem is variable among species according to their biological attributes (Alpert et al. 2000; Lodge 1993; Rejmánek et al. 2013). Many alien species can be invasive in some regions and have few or no negative impacts in other regions, even within the same country (Williamson 1996; Simberloff \& Rejmánek 2011). Biological invasions represent a biogeographical rather than a taxonomic phenomenon, and, thus, the invasion status should refer to each individual population and not to all populations of a certain species (Colautti \& MacIsaac 2004). Before including alien species in official lists of dangerous species and expending resources in their eradication or control, clear criteria are necessary in order to differentiate those species requiring management actions in each biogeographical region. Careful prioritization is necessary to optimize the allocation of resources (Hiebert 1997; Moody \& Mack 1988; Rouget et al. 2002; Rejmánek et al. 2013).

A third problem related to biological invasions is the unclear differentiation between risk assessment and impact evaluation. Risk assessment aims to prevent invasion by avoiding the introduction of harmful species to a new environment. Risk assessment protocols are often based upon the species attributes in their native ranges to predict if they can behave as invasive in the new range (e.g. Pheloung et al. 1999 in New Zealand; Tye (2001) in the Galapagos Islands; Werren (2001), in Australia). When dealing with already introduced species, it is a matter of impact evaluation. Some initiatives to assess and categorize invasive species based on their performance in the new range (impact) have been presented (e.g. Hiebert \& Stubbendieck (1993) in the USA; Colautti \& MacIsaac (2004); Khuroo et al. (2008) in India; Thomas et al. (2012) in Brazil). All these initiatives, 
as well as the present study, aim to prioritize management actions when the exotic species are already established in the new environment. This is particularly important for management plans of individual protected areas, but it is also relevant for decisions on the conservation and management of biodiversity on broader scales. Here, we propose a dichotomous key to classify plant species already established, on the basis of species population ecology, and discuss management implications related to invasion status and economic importance of the species, in addition to the ecological relevance of the invaded environment.

\section{A Protocol to Assess the Invasive Performance of a Plant Species in a Particular Biogeographical Region}

The first challenge to classify the species by their threat to natural ecosystems is to identify the attributes of the species or population that really matter. Considering what science has already explained about plant invasions, we suggest the attributes and categories listed in Table 1. These biological attributes (Table 1) were used to assemble a dichotomous key (Table 2), which allows the user to choose between successive pairs of alternative descriptions, until coming to the category that matches the species population under consideration.

We acknowledge that species categorized as ruderals are included among the invaders by most ecologists (Richardson et al. 2000; Williamson 1996; Pysek et al. 1995, 2004; Rejmánek et al. 2013). However, considering that the level of threat posed by alien species on the native biodiversity is much higher when they invade natural ecosystems than when they spread over disturbed areas, we decided to keep these two groups of species in distinct categories, adopting the term 'ruderal' for the last. This clear distinction and objective denomination is necessary for managers, since management interventions and the priority level of actions shall be remarkably distinct between these two groups of species.

\section{Additional Points to Consider When Prioritizing the Control of Biological Invasions}

In addition to the classification of the invasive species population based upon the criteria suggested here (Table 1), some other ecological and, particularly, technical and socioeconomic aspects must be considered by decision makers. Such elements are essential to set priorities, and to evaluate the convenience and liability for invasion control:

1) What is the ecological importance of the invaded site?

Losses caused by invasion are in decreasing order if the invaded site is a protected area, a remnant of native vegetation, a riparian zone, roadsides, or a degraded area. The less disturbed the ecosystem, the higher the priority for interventions aiming to reduce biodiversity losses. Occupation of degraded areas by exotic species can, in some cases, be positive, by recovering ecosystem services where the natives can hardly establish.

2) How fast can the invasive population expand?

Considering species for which eradication is recommended and possible, those that spread more rapidly shall be controlled first.

3) How important is the invasive species for the regional economy?

If the species has no social or economic importance, there are no constraints for its management or even eradication. If the species has economic or cultural relevance, control actions have to consider the social impact, besides the environmental aspects.

4) Can the invasive be replaced by a non invasive species that play the same function?

For those species that are important for people and are irreplaceable, eradication must be seen with restrictions. In these cases, actions must be directed towards the control of

Table 1. Attributes and categories to classify a plant species as invasive based on the threat it offers in a particular biogeographical region.

\begin{tabular}{|c|c|}
\hline Attributes & Categories \\
\hline \multirow[t]{2}{*}{ Origin } & $\begin{array}{l}\text { - taxa that evolved in the region, or reached it from another area where they are native without } \\
\text { human interference (native) }\end{array}$ \\
\hline & - taxa which owe their presence in the region to contemporary human activity (non native) \\
\hline \multirow[t]{2}{*}{ Natural regeneration potential } & $\begin{array}{l}\text { - taxa that occur only temporarily in the area, and are not able to persist for a long time without } \\
\text { human assistance }\end{array}$ \\
\hline & - form sustainable populations without human interference, but do not necessarily spread \\
\hline \multirow[t]{2}{*}{ Habitat type } & - do not establish in natural (undisturbed) ecosystems, spreading preferable over disturbed areas \\
\hline & $\begin{array}{l}\text { - form sustainable populations without human interference and spread over natural (undisturbed) } \\
\text { ecosystems }\end{array}$ \\
\hline \multirow[t]{2}{*}{ Dominance } & - do not inhibit native species regeneration and growth \\
\hline & $\begin{array}{l}\text { - change the composition or structure of the native plant community, inhibiting or suppressing the } \\
\text { regeneration of native species }\end{array}$ \\
\hline
\end{tabular}




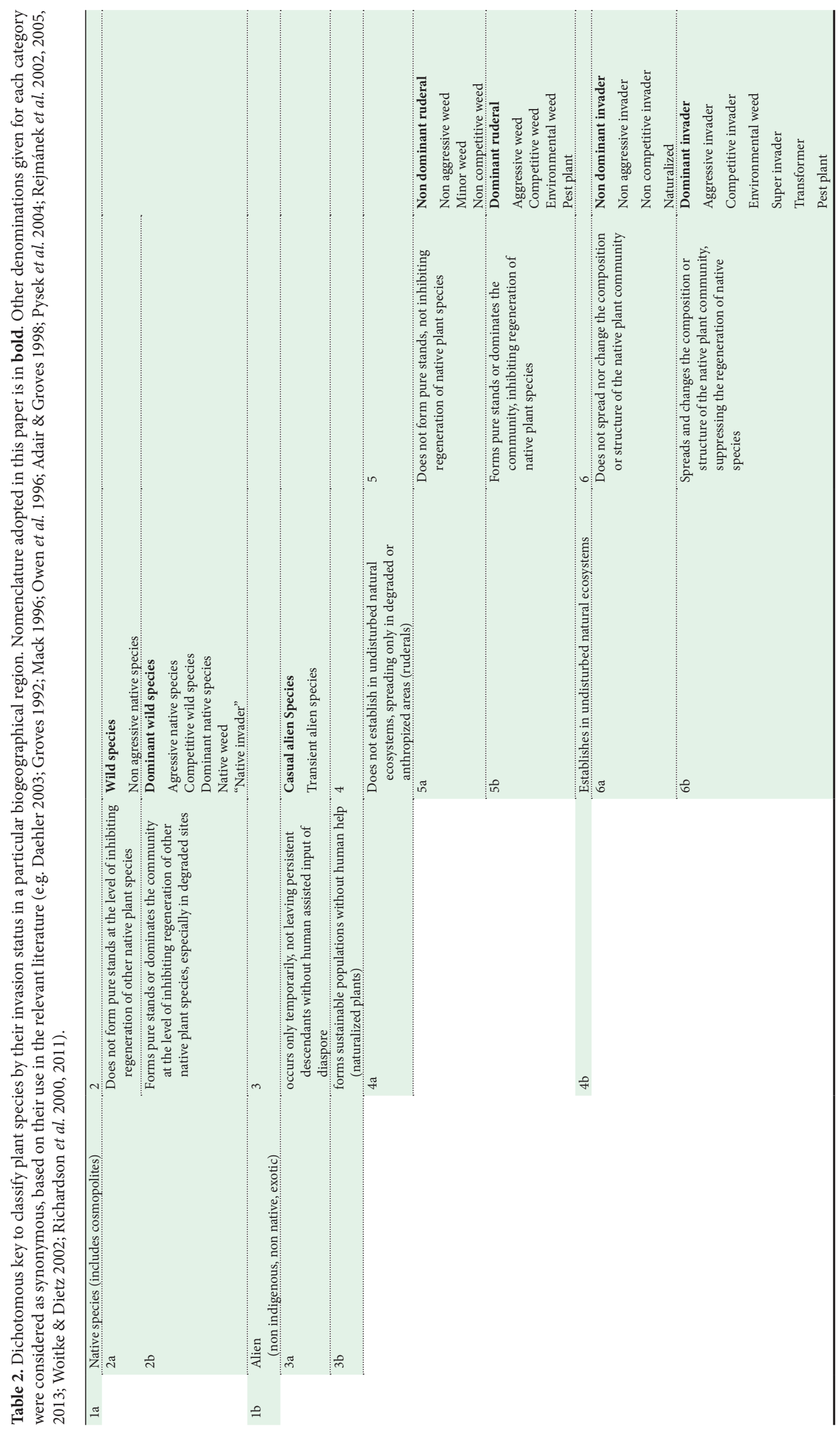


the invasive population, instead of eradication of the species. If replacement by a noninvasive is possible, eradication of the invader can be the goal, if technically possible.

5) Is the eradication technically feasible?

In some cases, eradication is technically impossible. Even if the species is a dominant invader, the only viable recommendation in such cases is avoiding population expansion over new habitats.

6) Is ecological restoration possible after eradication?

Environmental changes caused by invasive species can be irreversible in some situations and, thus, the native vegetation cannot be recovered. The success of restoration after eradication has been frequently hampered by re-invasion or establishment of a novel invader (Kettenring \& Adams 2011).

\section{Management Recommendations}

Prevention of biological invasions is the first strategy to be adopted, by avoiding the introduction of harmful species, which is much less costly than post-entry control (Finnoff et al. 2007). However, when dealing with already invaded areas, extirpation and control form the cornerstones of the practices recommended to restore invaded ecosystems. Depending on the category of the species in the region, from those provided by the classification key, management strategies recommended can vary in type and extent of intervention, as follows:
1) Management intervention:

a) Management not required;

b) Invasion avoidance (isolation of native ecosystems);

c) Population control (thinning);

d) Extirpation of the invasive population;

e) Disincentives for cultivation;

f) Cultivation permitted under strict rules;

g) Cultivation of the species prohibited.

2) Areas where interventions shall be applied:

a) The interior of legally protected areas (parks and reserves);

b) Other remnants of natural ecosystems;

c) Buffer zones of protected areas;

d) Areas under ecological restoration;

e) The entire biogeographical region (beyond natural ecosystems).

Management recommendations are presented for every category from the classification key (Table 3).

Table 3. General management recommendations for populations of plant species on the basis of their status as invasive (diagnosed according to the criteria from Table 2).

\begin{tabular}{|c|c|c|}
\hline Category & \multicolumn{2}{|r|}{ Management recommendation } \\
\hline Wild species & \multicolumn{2}{|c|}{ - management not required; } \\
\hline Dominant wild species & \multicolumn{2}{|c|}{ - overpopulation control in the interior of legally protected areas (low priority) } \\
\hline & \multicolumn{2}{|c|}{ - population control in areas under ecological restoration (low priority) } \\
\hline Casual alien species & \multicolumn{2}{|c|}{ - extirpation from legally protected areas (low priority) } \\
\hline Non dominant ruderal & \multicolumn{2}{|c|}{ - extirpation from legally protected areas (low priority) } \\
\hline Dominant ruderal & \multicolumn{2}{|c|}{ - extirpation from legally protected areas (intermediate priority) } \\
\hline & \multicolumn{2}{|c|}{ - extirpation from areas under ecological restoration (high priority) } \\
\hline & \multicolumn{2}{|c|}{ - discouragement of cultivation in the buffer zones of protected areas (intermediate priority) } \\
\hline Non Dominant Invader & \multicolumn{2}{|c|}{ - extirpation from protected areas (intermediate priority) } \\
\hline & \multicolumn{2}{|c|}{ - disincentives to cultivation in the buffer zone of protected areas (low priority) } \\
\hline & \multicolumn{2}{|c|}{ - Invasion avoidance - isolation of the natural ecosystems (low priority) } \\
\hline \multirow[t]{8}{*}{ Dominant Invader } & \multirow[t]{2}{*}{ Irrelevant for the regional economy } & - extirpation from the whole biogeographical region (high priority) \\
\hline & & - cultivation prohibited in the whole region (high priority) \\
\hline & \multirow[t]{6}{*}{ Relevant for the regional economy } & - extirpation from legally protected areas (high priority) \\
\hline & & - extirpation from other natural ecosystems (high priority) \\
\hline & & - extirpation from areas under ecological restoration (high priority) \\
\hline & & - Invasion avoidance - isolation of the natural ecosystems (high priority) \\
\hline & & - disincentives to cultivation (high priority) \\
\hline & & $\begin{array}{l}\text { - cultivation permitted under strict rules (permanent invasion } \\
\text { control by those cultivating the species) (high priority) }\end{array}$ \\
\hline
\end{tabular}




\section{Invasiveness, Biogeography, Economy and Management}

Risk assessment should be reinforced to avoid the spread of exotic species which can potentially perform as invasive in a new environment. This is not related, however, to management decisions. For those species already introduced with populations established in the new range, the performance of the species and the consequences of the invasion need to be evaluated before management decisions.

Since the status of invasion of a species varies greatly among regions, the categorization of plants in the context of biological invasions must be restricted to individualized biogeographical regions, where at least soil and climate conditions are relatively homogeneous. These are environmental factors governing the adaptation of a species to a geographic range and, consequently, to the local invasiveness of the species (Lodge 1993; Kolar \& Lodge 2001; Noble 1989; Rejmánek \& Richardson 1996) and to the invasibility of the habitats (Crawley 1987; Goodwin et al. 1999; Lonsdale 1999; Prieur-Richard \& Lavorel 2000; Shea \& Chesson 2002; Thuiller et al. 2005). Some alien species seem to have few or no negative impacts in certain regions, but behave as dominant invaders in other regions (Williamson 1996; Simberloff \& Rejmánek 2011). Management strategies, therefore, can be settled for the biogeographical region as a whole, even when it contains more than one population of the same species, as they will perform similarly under homogeneous soil and climate conditions.

By incorporating the socioeconomic relevance of the species into management decisions, we put the subject under a sustainable development perspective. Permanently controlling the spread of an alien species over natural ecosystems can present a benefit:cost ratio better than extirpation in cases of economically very important species that cannot be immediately replaced in the regional economy. In these cases, the costs of invasion control shall be incorporated to the supply chain.

As observed by Davis (2011, p. 368),

"[...] the ecological impacts of introduced species are many, and they vary from species to species, and environment to environment. Invasion biologists have only begun to understand the array and extent of these effects."

There is no widely recognized protocol to diagnose invasion impacts, and this has been an obstacle to be surpassed. Although the knowledge on invasive plant species has increased considerably, our ability to predict their impacts, or even measure them by using standardized methods, is still very rudimentary (Rejmánek et al. 2013). The simple observation of the species occurrence outside its native range, even reported by scientists, is important as the first step in invasion detection, but is certainly not enough to label a species as invasive or harmful for an entire region or a country as a whole. We need, at first, to apply proper ecological methodology in order to assess the dimensions and consequences of the invasion by different species in distinct ecological regions. Thenceforth, for aggressive invaders, which can displace native species and effectively cause biodiversity losses or changes in ecosystem functioning (the dominant invaders from the dichotomous key, in Table 2), urgent eradication experiments are needed in order to find technically, ecologically and economically feasible eradication practices and restoration techniques.

The framework that we described here can assist the managers and policy makers when defining and prioritizing actions related to alien plant species. For its effectiveness, however, ecologists must be involved in the diagnosis of the invasion status. The categorization of a species as invader demands specific studies on the species population in the invaded environment. We expect that the dichotomous key and the management recommendations proposed here can help improving the selection of which invasive species should be managed at first within each ecoregion and, particularly, which alien species do not require efforts or resources to their eradication or control.

\section{Acknowledgements}

The authors thank James Aronson, Marcel Rejmánek and two anonymous reviewers for their comments on the previous versions of this manuscript. G.D. thanks to Conselho Nacional de Desenvolvimento Científico e Tecnológico - CNPq, for productivity grant. RCRA thanks to CNPq, CAPES and Fulbright, for the Ph.D. grants.

\section{References}

Abreu RCR \& Durigan G, 2011. Changes in the plant community of a Brazilian grassland savannah after 22 years of invasion by Pinus elliottii Engelm. Plant Ecology \& Diversity, 4:269-278. http://dx.doi.org/10.1080/17550874.2011.594101

Abreu RCR \& Rodrigues PJF, 2010. Exotic tree Artocarpus heterophyllus (Moraceae) invades the Brazilian Atlantic Rainforest. Rodriguésia, 61:677-688.

Adair RJ \& Groves RH, 1998. Impact of Environmental Weeds on Biodiversity: a Review and Development of a Methodology. Canberra: Environment Australia.

Almeida RS et al., 2010. Campo sujo úmido: fisionomia de Cerrado ameaçada pela contaminação de Pinus elliottii Engelm. na Estação Ecológica de Itapeva, estado de São Paulo. Revista do Instituto Florestal, 22:71-91.

Alpert P, Bone E \& Holzapfel C, 2000. Invasiveness, invasibility and the role of environmental stress in the spread of non-native plants. Perspectives in Plant Ecology Evolution and Systematics, 3:52-66. http://dx.doi. org/10.1078/1433-8319-00004

Armstrong S, 1995. Rare plants protect Cape's water supplies. New Scientist, 11:8.

Convention on Biological Diversity - CBD, 2000. Cartagena Protocol on Biosafety to the Convention on Biological Diversity. Montreal: Secretariat of the Convention on Biological Diversity. 
Colautti RI \& MacIsaac HJ, 2004. A neutral terminology to define 'invasive' species. Diversity and Distributions, 10:135-141. http://dx.doi.org/10.1111/j.1366-9516.2004.00061.x

Crawley MJ, 1987. What makes a community invasible? In: Gray AJ, Crawley MJ \& Edwards PJ (eds.). Colonization, Succession and Stability. Oxford: Blackwell Scientific Publications. p. 429-453.

Cronk QCB \& Fuller JL, 1995. Plant Invaders. New York: Chapman and Hall.

Daehler CC, 2001. Two ways to be an invader, but one is more suitable for ecology. Bulletin of the Ecological Society of America, 82:101-102.

Daehler CC, 2003. Performance comparisons of co-occurring native and alien invasive plants: implications for conservation and restoration. Annual Review of Ecology, Evolution, and Systematics, 34:183-211. http://dx.doi.org/10.1146/annurev. ecolsys.34.011802.132403

D’Antonio CM, Dudley TL \& Mack M, 1999. Disturbance and biological invasions: direct effects and feedbacks. In: Walker LR (ed.). Ecosystems of Disturbed Ground. New York: Elsevier.

Davis MA, 2011. Invasion biology. In: Simberloff D \& Rejmánek M (eds.). Encyclopedia of Biological Invasions. Los Angeles: University of California Press. p. 364-369.

Davis MA \& Thompson K, 2000. Eight ways to be a colonizer; two ways to be an invader: a proposed nomenclature scheme for invasion ecology. ESA Bulletin, 81:226-230.

Davis MA \& Thompson K, 2001. Invasion terminology: should ecologists define their terms differently than others? No, not if we want to be of any help! Bulletin of the Ecological Society of America, 82:206.

Dislich R, Kisser N \& Pivello VR, 2002. A invasão de um fragmento florestal em São Paulo (SP) pela palmeira australiana Archontophoenix cunninghamiana. H. Wendl. \& Drude. Revista Brasileira de Botânica, 25:55-64. http:// dx.doi.org/10.1590/S0100-84042002000100008

Ehrenfeld JG, 2010. Ecosystem consequences of biological invasions. Annual Review of Ecology, Evolution and Systematics, 41:59-80. http://dx.doi.org/10.1146/ annurev-ecolsys-102209-144650

Finnoff D et al., 2007. Take a risk: Preferring prevention over control of biological invaders. Ecological Economics, 62:216-222. http://dx.doi.org/10.1016/j.ecolecon.2006.03.025

Goodwin et al., 1999. Predicting invasiveness of plant species based on biological information. Conservation Biology, 13:422426. http://dx.doi.org/10.1046/j.1523-1739.1999.013002422.x

Groves RH, 1992. Weed ecology, biology and spread. Proceedings of the International Weed Control Congress, 1:83-88.

Hiebert RD \& Stubbendieck J, 1993. Handbook for Ranking Exotic Plants for Management and Control. Denver: US Department of Interior, National Park Service.

Hiebert RD, 1997. Prioritizing invasive plants and planning for management. In: Luken JO \& Thieret JW (eds.). Assessment and Management of Plant Invasions. New York: Springer. p. 195-212. http://dx.doi.org/10.1007/978-1-4612-1926-2_15
Hoffmann WA et al., 2004. Impact of the invasive alien grass Melinis minutiflora at the savanna-forest ecotone in the Brazilian Cerrado. Diversity and Distributions, 10:99-103. http://dx.doi.org/10.1111/j.1366-9516.2004.00063.x

International Union for Conservation of Nature - IUCN, 2000. Guidelines for the Prevention of Biodiversity Loss Caused by Alien Invasive Species. Gland: IUCN The World Conservation Union.

Kettenring KM \& Adams CR, 2011. Lessons learned from invasive plant control experiments: a systematic review and meta-analysis. Journal of Applied Ecology, 48: 970-979. http://dx.doi.org/10.1111/j.1365-2664.2011.01979.x

Khuroo AA et al., 2008. Operational characterization of alien invasive flora and its management implications. Biodiversity and Conservation, 17:3181-3194. http://dx.doi.org/10.1007/ s10531-008-9419-z

Kolar CS \& Lodge DM, 2001. Progress in invasion biology: predicting invaders. Trends in Ecology \& Evolution, 16:199204. http://dx.doi.org/10.1016/S0169-5347(01)02101-2

Le Maitre DC et al. 1996. Invasive plants and water resources in the Western Cape Province, South Africa: modeling the consequences of a lack of management. Journal of Applied Ecology, 33:161-172. http://dx.doi.org/10.2307/2405025

Lodge DM, 1993. Biological invasions: lessons for ecology. Trends in Ecology and Evolution, 8:133-137. http://dx.doi. org/10.1016/0169-5347(93)90025-K

Lonsdale WM, 1999. Global patterns of plant invasions and the concept of invisibility. Ecology, 80:1522-1536. http://dx.doi. org/10.1890/0012-9658(1999)080[1522:GPOPIA]2.0.CO;2

Mack RN, 1996. Predicting the identity and fate of plant invaders: emergent and emerging approaches. Biological Conservation, 78:107-121. http://dx.doi.org/10.1016/0006-3207(96)00021-3

McKinney ML \& Lockwood JL, 1999. Biotic homogenization: a few winners replacing many losers in the next mass extinction. Trends in Ecology and Evolution, 14:450-453. http://dx.doi.org/10.1016/S0169-5347(99)01679-1

Medeiros RB \& Focht T, 2007. Invasão, prevenção, controle e utilização do capim-annoni-2 (Eragrostis plana Ness) no Rio Grande do Sul. Pesquisa Agropecuária Gaúcha, 13:105-114.

Moody ME \& Mack RN, 1988. Controlling the spread of plant invasions: the importance of nascent foci. Journal of Applied Ecology, 25:1009-1021. http://dx.doi.org/10.2307/2403762

Moro MF et al., 2012. Alienígenas na sala: o que fazer com espécies exóticas em trabalhos de taxonomia, florística e fitossociologia? Acta Botanica Brasilica, 26: 991-999. http:// dx.doi.org/10.1590/S0102-33062012000400029

Noble IR, 1989. Attributes of invaders and the invading process: terrestrial and vascular plants. In: Drake JA et al. (eds.). Biological Invasions: a global perspective. Chichester: John Willey \& Sons. p. 301-313. Pmid:2502688.

Owen SJ, Timmins, SM \& West CJ, 1996. Scoring the weedness of New Zealand's ecological weeds. Proceedings of Australian Weed Conference, 11:529-531.

Pegado CMA et al., 2006. Efeitos da invasão biológica de algaroba Prosopis juliflora (Sw.) DC. sobre a composição e a estrutura do estrato arbustivo-arbóreo da caatinga no Município de 
Monteiro, PB, Brasil. Acta Botanica Brasilica, 20: 887-898. http://dx.doi.org/10.1590/S0102-33062006000400013

Pheloung PC, Williams PA \& Halloy SR, 1999. A weed risk assessment model for use as a biosecurity tool evaluating plant introductions. Journal of Environmental Management, 57:239-251. http://dx.doi.org/10.1006/jema.1999.0297

Pivello VR, Shida CN \& Meirelles ST, 1999. Alien grasses in Brazilian Savannas: a threat to the biodiversity. Biodiversity and Conservation, 8:1281-1294. http://dx.doi. org/10.1023/A:1008933305857

Prieur-Richard AH \& Lavorel S, 2000. Invasions: the perspective of diverse plant communities. Austral Ecology, 25:1-7. http:// dx.doi.org/10.1046/j.1442-9993.2000.01033.x

Pysek P \& Richardson DM, 2010. Invasive species, environmental change and management, and health. Annual Review of Environment and Resources, 35:25-55. http://dx.doi. org/10.1146/annurev-environ-033009-095548

Pysek P et al., 1995. Plant Invasions: general aspects and special problems. Amsterdan: SPB Academic Publishing.

Pysek P et al., 2004. Alien plants in checklists and floras: towards better communication between taxonomists and ecologists. Taxon, 53:131-143. http://dx.doi.org/10.2307/4135498

Rejmánek M, 1995. What makes a species invasive? In: Pysek $\mathrm{P}$ et al. Plant Invasions: general aspects and special problems. Amsterdan: SPB Academic Publishing. p. 1-11.

Rejmanek M \& Richardson DM, 1996. What make someplant species more invasive? Ecology, 11: 1655-1661. http://dx.doi. org/10.2307/2265768

Rejmánek M et al., 2002. Biological invasions: politics and the discontinuity of ecological terminology. ESA Bull. 83:131-133.

Rejmánek M, Richardson DM \& Pysek P, 2005. Plant invasions and invasibility of plant communities. In: Van der Maarel E (ed.). Vegetation Ecology. Oxford: Blackwell Science. p. 332-355.

Rejmánek M, Richardson DM \& Pysek P, 2013. Plant invasions and invasibility of plant communities. In: Van der Maarel E \& Franklin J (eds.). Vegetation Ecology. Chichester: Wiley-Blackwell. p. 387-424.

Richardson DM, Pysek P \& Carlton JT, 2011. A compendium of essential concepts and terminology in invasion ecology. In: Richardson DM (ed.). Fifty Years of Invasion Ecology: the legacy of Charles Elton. Chichester: Wiley-Blackwell. p. 409-420. PMid:21944073 PMCid:3419153.

Richardson DM et al., 2000. Naturalization and invasion of alien plants: concepts and definitions. Diversity and Distributions, 6:93-107. http://dx.doi.org/10.1046/j.1472-4642.2000.00083.x

Rosenzweig ML, 2001. The four questions: what does the introduction of exotic species do to diversity? Evolutionary Ecology Research, 3:361-367.
Rouget $\mathrm{M}$ et al. 2002. Commercially important trees as invasive aliens: towards spatially explicit risk assessment at a national scale. Biological Invasions, 4:397-412. http:// dx.doi.org/10.1023/A:1023611713339

Shea K \& Chesson P, 2002. Community ecology theory as a framework for biological invasions. Trends in Ecology and Evolution, 17:170-176. http://dx.doi.org/10.1016/ S0169-5347(02)02495-3

Simberloff D, Parker IM \& Windle PN, 2005. Introduced species policy, management and future research needs. Front Ecol Environ, 3:12-20. http://dx.doi. org/10.1890/1540-9295(2005)003[0012:ISPMAF]2.0.CO;2

Simberloff D \& Rejmánek M, 2011. Encyclopedia of Biological Invasions. Los Angeles: University of California Press.

Thomas et al., 2012. Using space-for-time substitution and time sequence approaches in invasion ecology. Freshwater Biology, 57:2401-2410. http://dx.doi.org/10.1111/fwb.12005

Thuiller W et al., 2005. Niche-based modelling as a tool for predicting the risk of alien plant invasions at a global scale. Global Change Biology, 11:2234-2250. http://dx.doi. org/10.1111/j.1365-2486.2005.001018.x

Tye A, 2001. Invasive plant problems and requirements for weed risk assessment in the Galápagos Islands. In: Groves RH, Panetta FD \& Virtue JG (eds.). Weed Risk Assessment. Melbourne: CSIRO Publishing. p. 153-175.

Wells MJ et al., 1986. The history of introduction of invasive alien plants to southern Africa. In: Macdonald IAW, Kruger FJ \& Ferrar AA (eds.). The Ecology and Management of Biological Invasions in Southern Africa. Cape Town: Oxford University Press. p. 21-35

Werren G, 2001. Environmental Weeds of the Wet Tropics Bioregion: risk assessment and priority ranking. Australia: Cooperative Research Centre for Tropical Rainforest Ecology and management. Available from: $<\mathrm{http} / / / w w w . j c u . e d u . a u /$ rainforest/publications/environ_weeds.pdf $>$.

Williamson MH, 1996. Biological Invasions. London: Chapman and Hall.

Woitke M \& Dietz H, 2002. Shifts in dominance of native and invasive plants in experimental patches of vegetation. Perspectives in Plant Ecology, Evolution and Systematics, 5:165-184. http://dx.doi.org/10.1078/1433-8319-00032

Zanchetta D \& Diniz FV, 2006. Estudo da contaminação biológica por Pinus spp em três diferentes áreas na Estação Ecológica de Itirapina (SP, Brasil). Revista do Instituto Florestal, 18:1-14.

Zenni RD \& Ziller SR, 2011. An overview of invasive plants in Brazil. Revista Brasileira de Botânica, 34:431-446. http:// dx.doi.org/10.1590/S0100-84042011000300016

Received: February 2013

First Decision: April 2013 Accepted: June 2013 